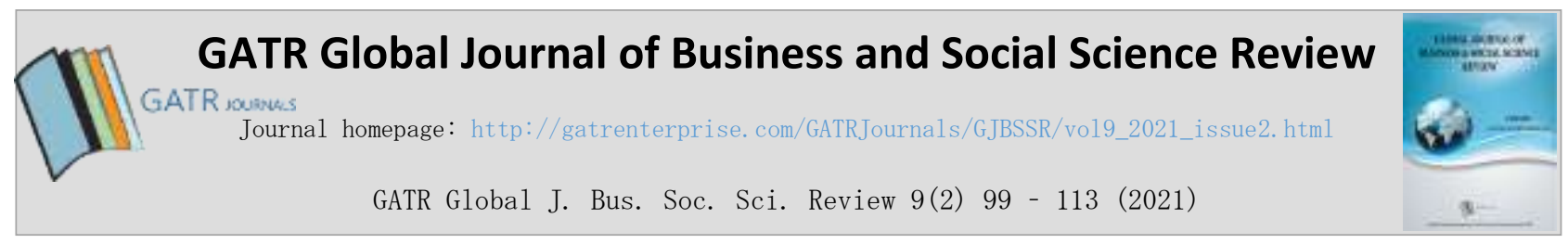

\title{
Exploring Fraudulent Honey Cases from Readily Available Food Fraud Databases
}

\author{
Nur Nisaa Ahmad ${ }^{1}$, Siti Nurhayati Khairatun ${ }^{2 *}$ \\ ${ }^{1}$ Faculty of Food Science and Technology, Universiti Putra Malaysia, 43400 UPM Serdang, Selangor, Malaysia. \\ ${ }^{2}$ Department of Food Service \& Management, Faculty of Food Science and Technology, Universiti Putra Malaysia, \\ 43400 UPM Serdang, Selangor, Malaysia.
}

\begin{abstract}
Objective - Honey has been identified statistically, from an extensive record of scholarly journals and media reports, as one of the most adulterated ingredients. It has a long history of dilution, substitution, misrepresentation of floral sources, and geographical origin. Despite the growing reported honey adulteration cases, the global honey market has been retaining its dominance. According to Market Research Future, honey demand estimates to flourish at a substantial growth rate of 7.22\% during the forecast period of 2017-2023. Increasing demand and commercial value of honey motivate falsification and adulteration in honey. This paper aims to examine the underlying factor of honey fraud's existence and prevalence by reviewing the core issues in honey quality assurance from a commercial standpoint.

Methodology/Technique - This paper reports on the industry scale of honey fraud using data from existing food fraud databases. Honey fraud cases from Food Adulteration Incidents Registry (FAIR) and Food Fraud Summary Month Reports were extracted, reviewed, and summarized.

Finding - The findings begin with an overview of past cases and current standing of honey fraud, followed by identification of the types of fraudulent practices on honey, and lastly, highlighting the challenges in fighting honey fraud. Findings conclude the scale of honey fraud which is widespread and interconnected across the world. Honey fraud includes fraudulent admixing with sugars or lower quality honey and incorrect labeling of honey's geographical origin or floral source. Challenges in combatting honey fraud are primarily due to financial motivations for producing and selling fraudulent honey and low control measures in the traceability system.

Novelty - This paper reports on the scale of honey fraud in the industry using data from the existing food fraud database. Compared to the abundance of research reporting on the latest most advanced detection method for honey authenticity, this paper examines the underlying factor on the existence of honey fraud and the fundamental control measure to be taken.
\end{abstract}

Type of Paper: Review.

JEL Classification: Q10, Q18.

Keywords: Fraudulent Honey; Honey Adulteration; Industrial Malpractice; Apiculture

Reference to this paper should be referred to as follows: Ahmad, N.N; Khairatun, S.N. (2021). Exploring Fraudulent Honey Cases from Readily Available Food Fraud Databases, GATR Global J. Bus. Soc. Sci. Review, 9(2), $99-113$. https://doi.org/10.35609/gjbssr.2021.9.2(1)

\section{Introduction}

Honey has been identified statistically, from an extensive record of scholarly journals and media reports, as one of the most adulterated ingredients.

\footnotetext{
* Paper Info: Revised: March 10, 2021

Accepted: June 30, 2021

* Corresponding author: Siti Nurhayati Khairatun

E-mail: snkhairatun@upm.edu.my

Affiliation: Universiti Putra Malaysia, Malaysia
} 
It has a long history of dilution, substitution, misrepresentation of floral sources, and geographical origin. Despite the growing reported cases of honey adulteration, the global honey market has been retaining its dominance. According to Market Research Future, honey demand estimates to flourish at a substantial growth rate of $7.22 \%$ during the forecast period of 2017-2023. Owing to its unique flavor characteristic and high nutritional value of scientifically proven medical health benefits, honey is generally perceived as highquality and high value (Oroian, Paduret \& Ropciuc, 2018). Increasing demand and commercial value of honey motivate falsification and adulteration in honey. Hence, a look into the past of the many cases of honey fraud is warranted. This paper aims to examine the underlying factor in honey fraud's existence and prevalence by reviewing the core issues in honey quality assurance from a commercial standpoint.

The Codex Standard 1981 defines honey as "a natural sweet substance produced by honeybees from the nectar of plants or from secretions of living parts of plants or excretions of plant-sucking insects on the living parts of plants, which the bees collect, transform by combining with specific substances of their own, deposit, dehydrate, store and leave in the honeycomb to ripen and mature." While the European Council Directive 2001/110/EC mentioned a similar definition but with a specific reference to Apis mellifera bees. Honey is divided into two main types, namely blossom honey, and honeydew honey. Blossom honey or nectar honey "comes from nectars of plants." Whereas honeydew honey "comes mainly from excretions of plant-sucking insects on the living parts of plants or secretions of living parts of plants."

This study aims to draw a background picture of honey fraud in the industry for public understanding and awareness. This study's outcome can be used as a knowledge base for general consumers to understand the scale of honey adulteration. Apart from that, food safety management practices, such as FSSC 22000, has recently incorporated food fraud vulnerability assessment and mitigation plan in their standard. The food industry could use the findings as a reference in developing their Threats Analysis Critical Control Point (TACCP) and Vulnerabilities Analysis Critical Control Point (VACCP) required in the standard.

\section{Methodology}

In 2012, the United States Pharmacopeia Convention (USP) initiated the effort to raise awareness of food fraud by documenting food fraud incidents in the past. Dr. John Spink, Director and Assistant Professor of Food Fraud Initiative, Michigan, led the research in compiling records from scientific literature, media publications, regulatory reports, judicial records, and trade association from around the world on a platform named Food Fraud Database (Food Fraud Database, n.d.). Journal of Food Science published the study under the article titled "Development and application of a database of food ingredient fraud and economically motivated adulteration from 1980 to 2010". Apart from that, USP also published the summarized results in their 8th edition of the Food Chemicals Codex (FoodNavigator.com, 2012). Findings showed olive oil, milk, honey, and saffron as the top common adulterated ingredients. This development of the database aimed to provide baseline information helpful to governments, agencies, producers, manufacturers, and retailers to assess a specific product's potential risks and vulnerability. This database was initially accessible at no cost to the public before it was acquired in 2018 by Decernis LLC, a consulting company providing technologyenabled global risk management solutions. Currently, it is accessible only through a paid subscription option.

Another available food fraud database compiling historical and current incidents involving economically motivated adulteration worldwide is the Food Adulteration Incidents Registry (FAIR). It is developed and maintained by the Food Protection and Defense Institute at the University of Minnesota (Food Adulteration Incidents Registry, n.d.). It is also on a paid subscription basis but cheaper by half the price Decernis is offering. However, it provides free access to incidents that happened five years back. A quick search on honey from Food Adulteration Incidents Registry reveals findings as presented in Table I. 
Table I. Incidents relating to honey adulteration.

(Source: Food Adulteration Incidents Registry)

\begin{tabular}{|c|c|c|c|c|}
\hline $\begin{array}{c}\text { Year } \\
\text { began- } \\
\text { ended }\end{array}$ & Adulterant(s) & $\begin{array}{c}\text { Method of } \\
\text { adulteration }\end{array}$ & $\begin{array}{l}\text { Originated } \\
\text { Location }\end{array}$ & Incident Summary \\
\hline $1979-1996$ & $\begin{array}{l}\text { Corn syrup; } \\
\text { dextrose; glucose; } \\
\text { invert sugar; } \\
\text { molasses }\end{array}$ & Dilution & $\begin{array}{c}\text { North } \\
\text { America, } \\
\text { United States }\end{array}$ & $\begin{array}{l}\text { A family-run honey and syrup business in } \\
\text { Dekalb, Mississippi was prosecuted by the } \\
\text { FDA for adulteration of "pure honey" and } \\
\text { "pure maple syrup" products with corn syrup. } \\
\text { The products were sold in old-fashioned } \\
\text { copper-colored tins at farmer's markets around } \\
\text { the United States. The company received } \\
\text { multiple notifications, but they continued to } \\
\text { produce and sell corn syrup labeled as pure } \\
\text { cane syrup, honey, maple syrup, molasses, and } \\
\text { sorghum syrup. }\end{array}$ \\
\hline 1988-1992 & Corn Syrup & Dilution & $\begin{array}{c}\text { North } \\
\text { America, } \\
\text { United States }\end{array}$ & $\begin{array}{l}\text { The U.S. Department of Justice and the FDA } \\
\text { charged a honey processing firm in Belleview, } \\
\text { Florida for selling honey blended with corn } \\
\text { syrup as "USDA Grade A" or "pure" honey, } \\
\text { resulting in an estimated } \$ 1 \text { million cost. }\end{array}$ \\
\hline $2001-2002$ & Chinese honey & $\begin{array}{l}\text { Transshipment / } \\
\text { Origin masking }\end{array}$ & $\begin{array}{l}\text { East Asia, } \\
\text { China }\end{array}$ & $\begin{array}{l}28 \text { consignments of Chinese honey were } \\
\text { imported into Australia as a product of } \\
\text { Singapore even though Singapore does not } \\
\text { have honeybees. In Australia, } 125 \text { shipping } \\
\text { containers were repackaged and relabeled as } \\
\text { Australian honey and exported to the United } \\
\text { States, Canada, and Europe. } 39 \text { shipments } \\
\text { arrived in the U.S. described as Australian } \\
\text { honey. }\end{array}$ \\
\hline $2002-2009$ & $\begin{array}{l}\text { Chinese honey; } \\
\text { Chloramphenicol; } \\
\text { Ciprofloxacin; } \\
\text { Furazolidone; } \\
\text { Norfloxacin }\end{array}$ & $\begin{array}{l}\text { Transshipment / } \\
\text { Origin masking }\end{array}$ & $\begin{array}{l}\text { East Asia, } \\
\text { China }\end{array}$ & $\begin{array}{l}\text { ALW Food Group and subsidiaries in the U.S. } \\
\text { and China conspired to ship } 606 \text { shipments of } \\
\text { Chinese-origin honey into the U.S. by declaring } \\
\text { alternate countries of origin to avoid paying } \\
\text { anti-dumping duties. The honey was } \\
\text { transshipped through countries including } \\
\text { Russia, India, Indonesia, Malaysia, Mongolia, } \\
\text { the Philippines, South Korea, Taiwan, and } \\
\text { Thailand. Some of the honey was contaminated } \\
\text { with unapproved antibiotics, and knowingly } \\
\text { sold to U.S. customers. The fraud included the } \\
\text { creation of "shell" companies, falsification of } \\
\text { documents, and falsification of laboratory } \\
\text { testing results. More than } 2,400 \text { drums were } \\
\text { seized during a probe. The fraud allegedly } \\
\text { resulted in the avoidance of almost } \$ 80 \text { million } \\
\text { in anti-dumping duties. }\end{array}$ \\
\hline $2000-2004$ & Argentina honey & Mislabeling & $\begin{array}{l}\text { Western } \\
\text { Europe, } \\
\text { Scotland }\end{array}$ & $\begin{array}{l}\text { Honey jars with a cheap Argentinian substitute } \\
\text { were mislabeled and sold } 25 \text { liters to specialist } \\
\text { shops such as The Good Life in Wooler, } \\
\text { Northumberland. A rival beekeeper filed a } \\
\text { complaint with Trade Standards based on the }\end{array}$ \\
\hline
\end{tabular}




\begin{tabular}{|c|c|c|c|c|}
\hline & & & & $\begin{array}{l}\text { knowledge that conditions were poor and } \\
\text { honey yields were low from the previous year. } \\
\text { The fraudster beekeeper was fined } 600 \text { pounds. }\end{array}$ \\
\hline 2004-2004 & Chloramphenicol & $\begin{array}{l}\text { Transshipment / } \\
\text { Origin masking }\end{array}$ & $\begin{array}{c}\text { North } \\
\text { America, } \\
\text { Canada; East } \\
\text { Asia, China }\end{array}$ & $\begin{array}{l}\text { The Canadian Food Inspection Agency } \\
\text { discovered five lots of honey distributed in } \\
\text { British Colombia contained residues of } \\
\text { Chloramphenicol. Chloramphenicol is banned } \\
\text { for use in honeybees in Canada. In 2002, } \\
\text { routine testing by the Canadian Food } \\
\text { Inspection Agency detected the drug in China- } \\
\text { origin honey. Recalls were initiated at the } \\
\text { supply chains to remove all honey of China } \\
\text { origin from the market. }\end{array}$ \\
\hline $2005-2005$ & Chinese honey & $\begin{array}{l}\text { Transshipment / } \\
\text { Origin masking }\end{array}$ & $\begin{array}{l}\text { East Asia, } \\
\text { China; North } \\
\text { America, } \\
\text { United States }\end{array}$ & $\begin{array}{l}\text { Two companies were found guilty and served } \\
\text { time in jail for transshipping mislabeled honey } \\
\text { and avoiding anti-dumping duties. It was } \\
\text { revealed that these firms were closely } \\
\text { interconnected with ALW Food Group. }\end{array}$ \\
\hline $2005-2008$ & $\begin{array}{l}\text { Antibiotics; } \\
\text { Chinese honey; } \\
\text { Ciprofloxacin }\end{array}$ & Mislabeling & $\begin{array}{l}\text { East Asia, } \\
\text { China }\end{array}$ & $\begin{array}{l}\text { Chinese honey worth more than } \$ 1.4 \text { million } \\
\text { was sent to the Philippines and Thailand, where } \\
\text { it was repackaged and relabeled to hide its true } \\
\text { country of origin. Authorities began } \\
\text { investigating Rainier Cascade and Evergreen } \\
\text { Produce in } 2008 \text { and found evidence that the } \\
\text { honey was manufactured in China and shipped } \\
\text { using fraudulent documents. The anti-dumping } \\
\text { duties owed on the honey were more than } \$ 3.3 \\
\text { million. }\end{array}$ \\
\hline $2006-2013$ & $\begin{array}{l}\text { Cane sugar; corn } \\
\text { sugar; Turkish } \\
\text { honey }\end{array}$ & Mislabeling & $\begin{array}{l}\text { Middle East, } \\
\text { Turkey }\end{array}$ & $\begin{array}{l}\text { Australian Competition \& Consumer } \\
\text { Commission (ACCC) found Basfoods (Aust) } \\
\text { Pty Ltd guilty of misrepresenting its product } \\
\text { "Victoria Honey" when in fact it was produced } \\
\text { in Turkey. Inspectors also found that "Victoria } \\
\text { Honey" was made primarily from plant sugars } \\
\text { including corn and sugarcane. Basfoods was } \\
\text { required to publish a range of corrective notices } \\
\text { in addition to paying } \$ 30,600 \text { in penalties. }\end{array}$ \\
\hline $2008-2012$ & Chinese honey & $\begin{array}{l}\text { Transshipment / } \\
\text { Origin masking }\end{array}$ & $\begin{array}{l}\text { East Asia, } \\
\text { China }\end{array}$ & $\begin{array}{l}\text { Two executives of Groeb Farms knowingly } \\
\text { purchased and facilitated the transportation of } \\
\text { at least } 1,578 \text { containers of Chinese honey that } \\
\text { was illegally smuggled into the U.S. The honey } \\
\text { was either declared as originating from other } \\
\text { countries or was declared as sugar syrup to } \\
\text { avoid anti-dumping duties (estimated to } \$ 180 \\
\text { million). }\end{array}$ \\
\hline $2009-2011$ & Chinese honey & Mislabeling & $\begin{array}{l}\text { East Asia, } \\
\text { China; } \\
\text { Southeast } \\
\text { Asia, Taiwan }\end{array}$ & $\begin{array}{l}\text { Three men were apprehended and charged with } \\
\text { smuggling and providing false descriptions of } \\
\text { imported products in Jacksonville, Florida. } \\
\text { According to U.S. authorities, the individuals } \\
\text { labeled 55-gallon barrels of Chinese honey as } \\
\text { rice fructose to avoid the } \$ 1,150,000 \text { ( } \$ 2.63 \text { per } \\
\text { kilo) duty. A total of } 900 \text { mislabeled containers } \\
\text { were imported over } 2 \text { years. }\end{array}$ \\
\hline
\end{tabular}




\begin{tabular}{|c|c|c|c|c|}
\hline $2009-2012$ & $\begin{array}{l}\text { Chinese honey; } \\
\text { Chloramphenicol; } \\
\text { Vietnamese honey }\end{array}$ & $\begin{array}{l}\text { Transshipment / } \\
\text { Origin masking }\end{array}$ & $\begin{array}{l}\text { East Asia, } \\
\text { China }\end{array}$ & $\begin{array}{l}\text { Nearly } \$ 38 \text { million in tariffs were unpaid due to } \\
\text { a transshipment facilitated by a Texas honey } \\
\text { broker doing business under the name Honey } \\
\text { Solutions. Between } 2009-2012 \text {, Chinese honey } \\
\text { was shipped to the USA as honey produced in } \\
\text { India or Malaysia. Officials report that } 778 \\
\text { containers of honey were transshipped to the } \\
\text { US. Individuals were fined and jailed. The } \\
\text { owner also admitted to selling purported } \\
\text { Vietnamese honey tainted with } \\
\text { Chloramphenicol. }\end{array}$ \\
\hline $2011-2011$ & $\begin{array}{l}\text { Commercial } \\
\text { glucose; corn } \\
\text { syrup }\end{array}$ & Dilution & $\begin{array}{c}\text { South } \\
\text { America, } \\
\text { Argentina }\end{array}$ & $\begin{array}{l}\text { In Villa Elisa, Argentina, honey was found to } \\
\text { be diluted with corn syrup and/or commercial } \\
\text { glucose. The public was advised to refrain from } \\
\text { buying honey from the Chajari province. }\end{array}$ \\
\hline $2012-2012$ & $\begin{array}{l}\text { Addition of water; } \\
\text { sugar; sugar syrup }\end{array}$ & Dilution & $\begin{array}{l}\text { East Africa, } \\
\text { Zimbabwe }\end{array}$ & $\begin{array}{l}\text { Adulterated honey can be found at nearly every } \\
\text { black market in Marondera, Zimbabwe. It is } \\
\text { increasingly becoming difficult to differentiate } \\
\text { it from genuine honey because the packaging is } \\
\text { the same. Vendors have resorted to mixing } \\
\text { sugar syrup and honey due to the migration of } \\
\text { bees in Zimbabwe. }\end{array}$ \\
\hline $2012-2012$ & A syrup substance & Substitution & Unknown & $\begin{array}{l}\text { A London-based importer was fined after an } \\
\text { investigation by West Sussex Trading } \\
\text { Standards officers found that Hasbal Honey } \\
\text { with Syrup and Aynoor Honey substituted with } \\
\text { an alternate syrup substance. A total of } 2,484 \\
\text { jars of adulterated honey were seized and the } \\
\text { company was fined } £ 17,119 \text {. }\end{array}$ \\
\hline 2014-2014 & $\begin{array}{l}\text { Corn sugar; sugar; } \\
\text { sugar syrup; } \\
\text { Turkish honey }\end{array}$ & Mislabeling & $\begin{array}{c}\text { Middle East, } \\
\text { Turkey }\end{array}$ & $\begin{array}{l}\text { Australian Honey Bee Industry Council found } \\
\text { "Hi Honey" product, which was supplied by } \\
\text { Hume Import and Export Pty Ltd and branded } \\
\text { as Bera Foods, was made from sugar syrup. It } \\
\text { was mislabeled as honey made in Australia but } \\
\text { not Turkey. Bera Foods was fined to pay } \\
\$ 10,200 \text {. }\end{array}$ \\
\hline
\end{tabular}

Apart from that, the European Commission also published the Food Fraud Summary Month Reports, which started in September 2016. These monthly reports are available in two sections which are food fraud legal cases and news updates. By scanning through the reports, the findings on honey adulteration are tabulated in Table II. 
Table II. Incidents relating to honey adulteration.

(Source: European Commission's Food Fraud Summary Month Reports)

\begin{tabular}{|c|c|c|c|}
\hline Year & Month & Method of adulteration & Originated location \\
\hline 2016 & Nov & $\begin{array}{l}\text { Honey, jam, and olive oil from Ischia island originated from continental } \\
\text { Honey products were sold on and labelled as made in Ischia (island west } \\
\text { of Naples) to tourists. A raid discovered that products were originally } \\
\text { made on the continent (Cava de Tirreni, south of Naples). } \\
\text { Uruguayan honey may be exported as Brazilian organic honey } \\
\text { Honey exporters association of Uruguay claims that at least } 30 \% \text { of the } \\
\text { honey produced in Uruguay may be smuggled out and relabeled as a } \\
\text { high-value Brazilian organic product. }\end{array}$ & Uruguay \\
\hline \multirow[t]{4}{*}{2017} & Jan & $\begin{array}{l}\text { Belgian honey market prone to frauds } \\
\text { The Belgian Consumer Association "Test Achats" found that } 16 \text { out of } 28 \\
\text { tested kinds of honey }(57 \%) \text { showed some irregularities concerning } \\
\text { freshness, exogenous sugar content, floral composition, and/or } \\
\text { geographical origin. }\end{array}$ & Belgium \\
\hline & Feb & $\begin{array}{l}\text { Spanish parties ask for more accurate labelling of honey } \\
\text { Several Spanish political parties supported a motion to urge the } \\
\text { government to amend the labelling regulation for honey. They wanted the } \\
\text { actual country of origin to be mentioned on the label (instead of EU or } \\
\text { non-EU, currently) which allows consumers to identify the origin of the } \\
\text { product. } \\
\text { A portable infrared technique developed to test authentic South African } \\
\text { honey } \\
\text { Stellenbosch University developed a technique to test the authenticity of } \\
\text { South African honey based on infrared spectroscopy. The portable device } \\
\text { is said to be fast and non-destructive which becomes handy for on-the- } \\
\text { spot controls. The testing relies on a fingerprint typical of authentic } \\
\text { South African honey and can then detect foreign and adulterated } \\
\text { products. }\end{array}$ & South Africa \\
\hline & March & $\begin{array}{l}\text { Exportations of New Zealand honey rise by } 35 \% \text { in revenue } \\
\text { While the average price of honey is decreasing, the New Zealand } \\
\text { exportations reached NZD } 315 \text { million which represents an increase of } \\
+35 \% \text { compared to last year. This upward trend is explained by the high } \\
\text { quality and rising price of Manuka honey. } \\
\text { Canadian beekeepers blame adulterated honey for prices drop } \\
\text { Last year, the value of Canadian honey dropped by } 53 \text { million CAD } \\
\text { while the country imported } 6.6 \text { million kilograms of honey. The } \\
\text { Canadian Honey Council claimed it could be "transshipped adulterated } \\
\text { manufactured honey" asking for actions from the Canadian Food } \\
\text { Inspection Agency, suggesting investment in nuclear magnetic resonance } \\
\text { (NMR) testing, which can detect the sweetener's composition and place } \\
\text { of origin of honey. }\end{array}$ & New Zealand \\
\hline & April & $\begin{array}{l}\text { Manuka honey obtains its scientific definition. } \\
\text { The New Zealand government issued the official regulatory definition for } \\
\text { the premium Manuka honey. Based on a collection of } 800 \text { honey samples } \\
\text { from over } 20 \text { different honey types and } 16 \text { different countries, the study } \\
\text { extracted the measurable attributes (markers) typical of Manuka honey. } \\
\text { The expert also developed and validated the associated test methods } \\
\text { (chemical composition and pollen DNA). }\end{array}$ & New Zealand \\
\hline
\end{tabular}




\begin{tabular}{|c|c|c|}
\hline May & $\begin{array}{l}30 \text { tons of adulterated honey seized in Pakistan } \\
\text { The Punjab Food Authority raided a famous herbal company in the } \\
\text { province and found } 30 \text { tons of honey mixed with industrial-grade dyes. } \\
\text { Adulterated honey in Thailand } \\
\text { In Chiang Mai (Northern Thailand), seven people are suspected of selling } \\
\text { adulterated honey. They mixed normal beehive honey with corn syrup, } \\
\text { bee wax, sugar, and honey fragrance for financial profit. }\end{array}$ & Thailand \\
\hline & $\begin{array}{l}\text { Substandard honey in the Canadian market } \\
\text { The consumer magazine "Protegez-Vous" analyzed } 36 \text { kinds of honey } \\
\text { from the Canadian market and detected different types of adulteration: } \\
\text { addition of exogenous sugars, over-heating, and origin masking. } 11 \\
\text { samples did not comply with the purity and quality tests. }\end{array}$ & Canada \\
\hline Oct & $\begin{array}{l}\text { The controversy around "pure and natural" labelling of honey } \\
\text { The French authorities charged a honey producer honey in France for } \\
\text { abusive labelling of "pure and Natural" honey, stating that, by definition, } \\
\text { honey is pure and natural. However, the court dropped the allegations } \\
\text { after the defense argued on technical terms. }\end{array}$ & France \\
\hline Nov & $\begin{array}{l}\text { Fraud on Corsica PDO honey } \\
\text { French fraud control authorities demonstrated that a honey producer from } \\
\text { Corsica imported chestnut honey from continental France and sold it as } \\
\text { "AOP Miel de Corse". Honey from Corsica is the only PDO honey in } \\
\text { France besides the "Miel de Sapin des Vosges". } 600 \mathrm{~kg} \text { of the products } \\
\text { were seized, and the producer admitted the scam. } \\
\text { Flower honey marketed as Acacia seized in Tuscany } \\
\text { Italian authorities investigated a honey distributor involved in the } \\
\text { marketing of local and foreign honey (Romania, Croatia, Argentina). The } \\
\text { investigation revealed that the honey sold as acacia honey was, in fact, } \\
\text { plain flower honey that is usually sold } 40 \% \text { cheaper than acacia. } \\
\text { Therefore, } 22 \text { tons of the products were seized. }\end{array}$ & France \\
\hline Jan & $\begin{array}{l}\text { MEPs fight against fake honey } \\
\text { Some members of the European Parliament made several propositions to } \\
\text { support the EU honey sector. Besides bee colony protection, they } \\
\text { highlighted the need to develop effective laboratory analysis procedures, } \\
\text { such as nuclear magnetic resonance, and to tighten the traceability } \\
\text { obligations such as mentioning explicitly the country of origin. }\end{array}$ & EU \\
\hline Feb & $\begin{array}{l}\text { EU institutions to push for support of the honey sector } \\
\text { The EU addressed the decline in bee colonies or adulteration of imported } \\
\text { products. The Commission's Joint Research Centre organized a } \\
\text { roundtable meeting of the different actors in the field to identify ways of } \\
\text { detecting fraud in the honey supply chain and to find consensus on the } \\
\text { best practices to ensure authenticity. }\end{array}$ & EU \\
\hline March & $\begin{array}{l}\text { European Parliament requested better protection of bees and apiculture in } \\
\text { Europe } \\
\text { The European Parliament has requested the European Commission and } \\
\text { the Member States to initiate actions to protect bees and the apiculture } \\
\text { sector in Europe includes to increase the budget allocated to protect the } \\
\text { sector, banning the use of pesticides that can be harmful to bees, to } \\
\text { develop treatments for diseases that can affect bees. }\end{array}$ & EU \\
\hline Apr & $\begin{array}{l}\text { Mexican authorities support legit honey producers and traders } \\
\text { Mexican food authorities have started a system to protect lawful honey } \\
\text { producers and traders. One of the first initiatives is an app for } \\
\text { smartphones (BiotikApp) that allows consumers to trace information on }\end{array}$ & Mexico \\
\hline
\end{tabular}


apiculture activities such as blossoming in the areas where honey is produced. Honey fraud in Mexico involves the addition of maize, soya, and rice syrup to increase the volume of honey and mislabeling on the origin of the product.

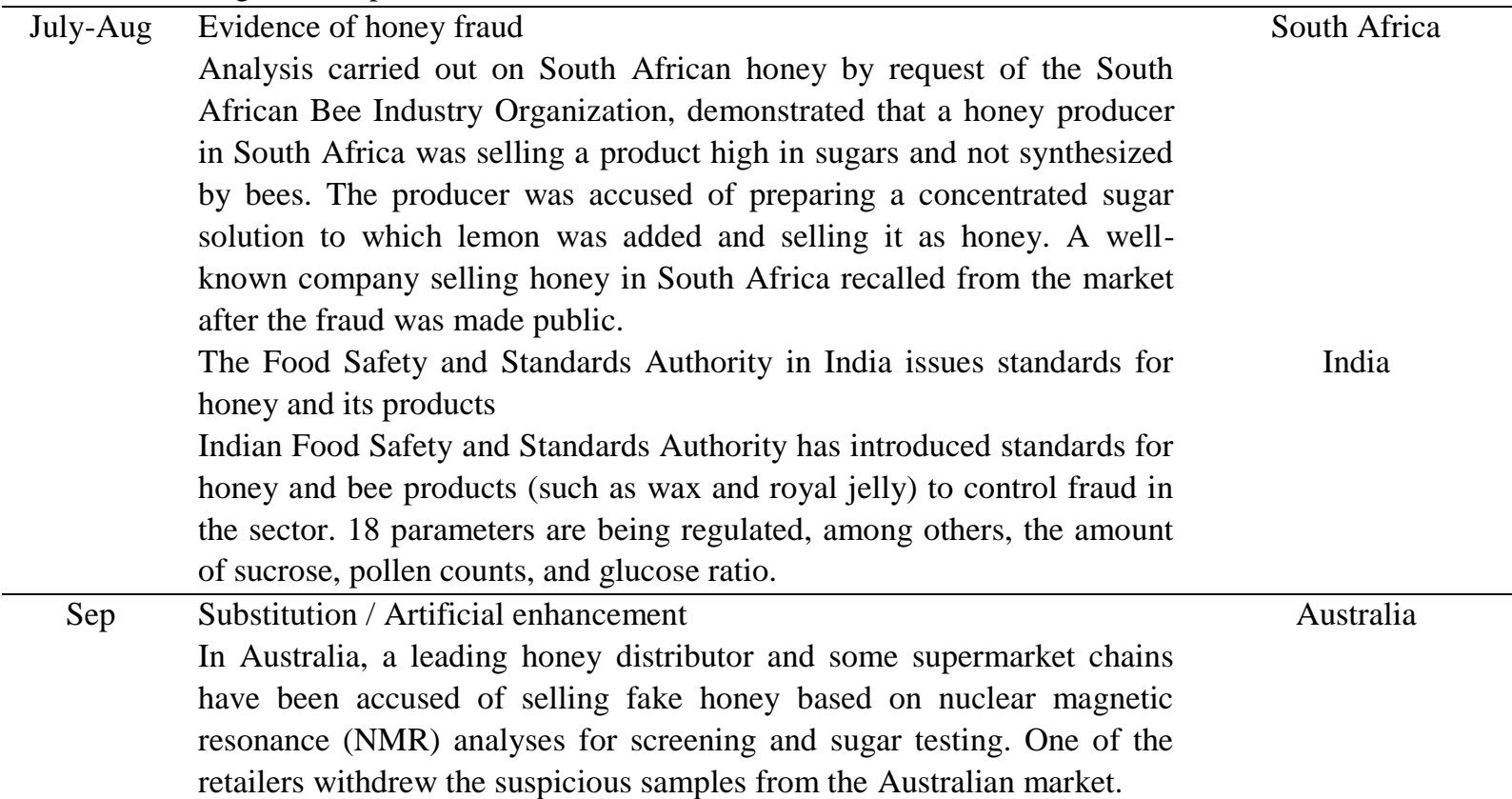

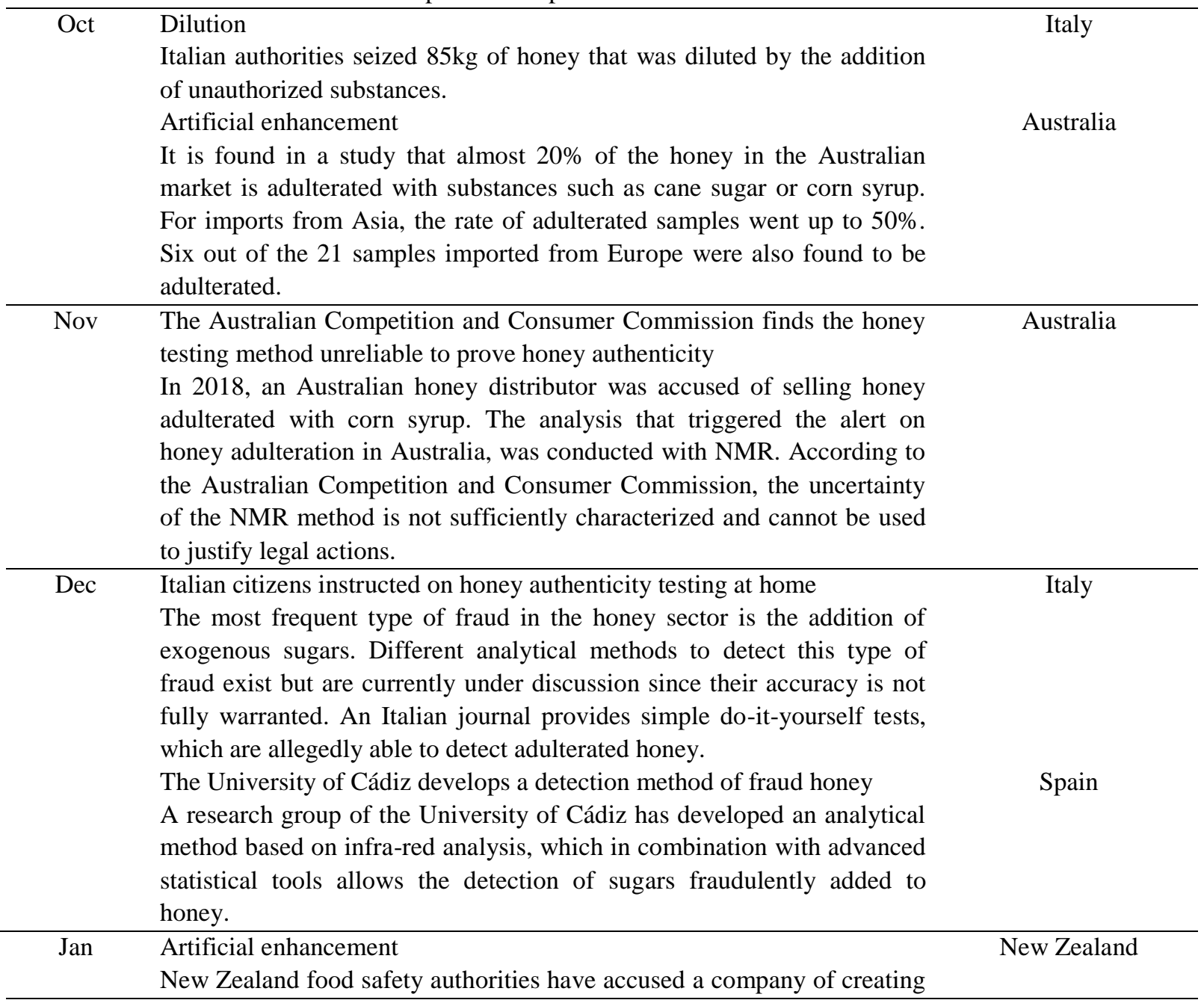


fake Manuka honey by adding to ordinary honey the substances methylglyoxal and dihydroxyacetone, which occur naturally in Manuka honey. The company exports products to other countries in Asia and the US.

\begin{tabular}{|c|c|c|}
\hline March & $\begin{array}{l}\text { Substitution / intentional distribution of contaminated products } \\
\text { The UK Food Standards Agency has warned consumers that honey sold } \\
\text { under the label of certain supermarket brands could be adulterated. A } \\
\text { British honey trader requested a laboratory in Germany to test honey } \\
\text { samples that he had imported, and the results triggered the warning. } \\
\text { Mandatory information about the geographical origin of honey required } \\
\text { in Spain } \\
\text { Spain requires an indication of the geographical origin of honey sold in } \\
\text { the Spanish market. In the case of blended honey from the different } \\
\text { geographic origins, the countries concerned have to be listed alongside } \\
\text { the percentage of each in the blend. }\end{array}$ & Spain \\
\hline Apr & $\begin{array}{l}\text { Dilution } \\
\text { A producer of manuka honey in New Zealand has admitted to adding an } \\
\text { extraneous substance to increase the volume of honey and ultimately } \\
\text { maximize economic gain. }\end{array}$ & \\
\hline June & $\begin{array}{l}\text { Artificial enhancement } \\
\text { A honey producer in New Zealand has been found guilty of adding } \\
\text { methylglyoxal and dihydroxyacetone to } 14 \text { tons of honey during its } \\
\text { processing to imitate manuka honey, in which both compounds naturally } \\
\text { exist. }\end{array}$ & \\
\hline Jul-Aug & $\begin{array}{l}\text { Dilution / Substitution } \\
22 \% \text { of the tested imported honey samples in controls carried out by the } \\
\text { Canadian Food Inspection Agency turned out to be diluted with } \\
\text { exogenous sugars such as sugar cane and rice syrup. } \\
\text { Mislabeling } \\
\text { Seven thousand honey jars have been seized in Italy because the labels } \\
\text { used did not fulfil the requirements of the legislation. } \\
\text { Traceability information mandatory for Argentinian honey Argentina } \\
\text { In compliance with the new law, all honey produced in Argentina from } \\
2019-2020 \text { onwards is required to provide traceability information. The } \\
\text { information will cover the full production chain, beginning with the } \\
\text { origin and extraction facilities. } \\
\text { The adverse climate in Italy } \\
\text { Honey production in Italy has decreased this year due to adverse climatic } \\
\text { conditions. This situation accounts for the significant loss suffered by } \\
\text { honey producers and increases the risk of fraud in the honey sector. } \\
22 \% \text { of imported honey in Canada contained extraneous sugars } \\
\text { In } 2018,22 \% \text { of the imported honey samples were found to contain } \\
\text { extraneous added sugars such as sugar cane, syrup of rice, and syrup of } \\
\text { corn. }\end{array}$ & Argentina \\
\hline Sep & $\begin{array}{l}\text { Traceability information mandatory for Italian honey } \\
\text { Due to adverse climatologic conditions, the production of honey in Italy } \\
\text { has fallen by half in } 2019 \text {. }\end{array}$ & Italy \\
\hline Oct & $\begin{array}{l}\text { A dramatic fall in honey production in Spain } \\
\text { Due to adverse climate conditions, the production of honey in the } \\
\text { Spanish island of Gran Canaria has fallen to } 10 \% \text { of the average output. } \\
\text { Extreme heat in the south of the island and irregular seasonal cycles in } \\
\text { the north affected the ability of the bees to produce honey for their } \\
\text { survival. The massive fires on the island destroyed } 1000 \text { hives. Fraud }\end{array}$ & Spain \\
\hline
\end{tabular}


Other publicly available references that focus solely on food fraud reports are a Trello website named 'Food Fraud Risk Information' (Food Fraud Risk Information, n.d.). However, it only serves as an informal platform of information curated by an online consultancy named Food Fraud Advisors. An entry is recorded for the review on honey adulteration under their grouping of 'sweeteners, honey, and syrups.' Unfortunately, this can only serve as a reading since the accuracy and credibility cannot be verified as the information source was not mentioned.

Reports from the databases mentioned earlier are assessed and analyzed to review past incidents on honey fraud cases, identify the common types of malpractice being done in the honey industry, and highlight the core issues and challenges in preserving honey authenticity. Figure I exhibit a flowchart for reviewing information from databases to review past incidents of honey fraud cases.

Identify database of food fraud cases

Available credible sources:

1) Food Fraud Database initially developed by U.S. Pharmacopeial Convention, now owned by Decernis LLC

2) Food Adulteration Incidents Registry (FAIR) by Food Protection Defense Institute, University of Minnesota

3) Food Fraud Summary Month Reports by European Commission

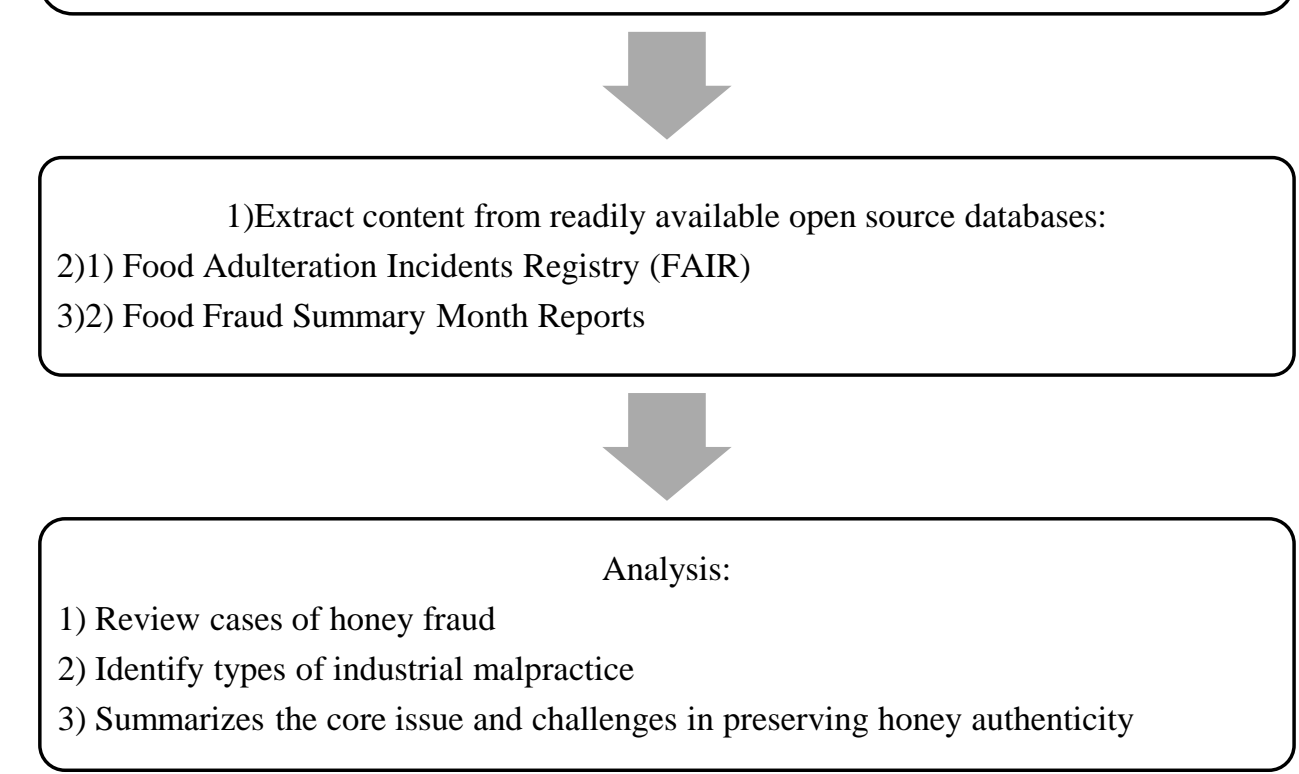

Figure I. Process flowchart for reviewing information from databases. 


\section{Results \& Discussion}

\subsection{Honey Fraud in the United States}

American's annual honey consumption is around 400 million pounds, while its annual honey production is around 150 million pounds. This massive deficit motivates the honey laundering pot, of which China being the most notorious producer of counterfeit honey. Chinese honey was transshipped to other Asian countries, repackaged, and given fake labels and identity certificates before entering the U.S. market (Bennett, 2013).

In December 2001, the Commerce Department imposed anti-dumping duties on Chinese-origin honey, a tariff barrier to protect honey from being sold at less than fair market value. Chinese honey's undercutting of price had prevented U.S. local beekeepers from trading domestic honey fairly (U.S. Attorney's Office, 2013). Not long after, Chinese honey was transshipped to other Asian countries before being shipped to the U.S. to circumvent import tariffs and border quality control check,

In 2008, the U.S. Immigration and Customs Enforcement (ICE) and Homeland Security Investigations (HSI), both of which are the federal law enforcement agency and the investigative arm, respectively, under the Department of Homeland Security, started the "Honeygate" undercover. It ended up becoming the largest food fraud investigation in U.S. history (Bottenmiller, 2013; Coursey \& Caryl, 2013; Schneider, 2011). The first phase of the investigations focuses on the supply side involving the circumvention of 2001 anti-dumping duties on Chinese honey through illegal imports, including transshipment and mislabelling. In contrast, the second phase targets the demand side, including the purchasers, processors, traders, and facilitators of illegally imported honey. The first phase began in 2008 when federal authorities investigated Alfred L. Wolff (ALW) company. To date, ALW, a German food conglomerate, is known as the biggest honey fraud player in U.S. history, with about $\$ 80$ million circumventions in anti-dumping duties by illegal importation of Chinese-origin honey. Using findings from the first phase of 'Honeygate,' the second phase of the investigation involved allegations of illegal buying, processing, and trading of smuggled honey. Groeb Farms, Honey Solution, and National Honey Inc. were all found guilty of purchasing illegal Chinese honey imports, which were transshipped to other Asian countries, namely Indonesia, Malaysia, Mongolia, Thailand, India, and Vietnam, before being shipped to the U.S. The honey was misrepresented as sugars and syrups with KBB Express Inc., which served as the U.S agent in facilitating the importation process. It is interesting to note that this was not a first for Groeb Farms. Their fraudulent practice goes way back to 1995 when being indicted for selling honey blended with corn syrup as "USDA Grade A" or "pure" honey (Breen, 2010). Also, all these companies being found guilty were not small players. They are among the largest honey suppliers and packers in the U.S and had avoided more than $\$ 150$ million worth in total of anti-dumping duties.

Honey laundering is not only a problematic financial fraud in the U.S., but most importantly, harms legitimate business and public trust in honey integrity.

\subsection{Honey fraud in Europe}

The European Union (EU) is the world's second-largest honey producer after China, led by Romania, Spain, and Hungary. Despite that, honey consumption exceeds their production. EU still needs to import honey to supply its domestic consumption. China, as the world's leading honey producer, accounts for half of Europe's honey imports.

In 2016, the Joint Research Centre (JRC) under the European Commission conducted a study to determine the prevalence of fraudulent practices in honey marketing. It was discovered that $14.2 \%$ of the 893 jars of honey analyzed did not follow EU standards because it was adulterated with sugars (Aries et al., 2016).

Early 2018, Members of the European Parliament (MEPs) proposed an EU-wide broad, long-term apiculture strategy, backed by request from beekeepers from the 27 member countries, with these three major concerns: (1) bee health, (2) honey fraud, and (3) beekeeping activities. To reduce honey fraud, MEP proposed combatting counterfeit honey imports by tightening border inspections and controls in the internal 
market, hardening traceability requirements by testing all imported honey, developing effective laboratory analysis procedures, and imposing tougher penalties against offenders. (EcoDiario.es, 2018; Europa NU, 2018)

\subsection{Honey fraud in New Zealand}

New Zealand is known for its specialty, which is the Manuka honey. However, the production of Manuka honey is not in sync with the demand. In early 2014, New Zealand's Ministry for Primary Industries (MPI) revealed the mismatch between production and sales of Manuka honey, 1,700 tonnes of Manuka honey production versus 10,000 tonnes of honey labeled Manuka sales. This finding was acknowledged by Comvita Ltd, one of the biggest Manuka honey producers, for their inability to support consumers' demand, especially within the international market, such as the U.S. and Canada (NZ Herald, 2018).

In March 2017, MPI introduced a scientific definition of Manuka honey, the first of its kind (Ministry for Primary Industries, 2019). After the introduction, Evergreen Life Ltd, an Auckland-based health company, was charged with artificially adding synthetic methylglyoxal (MGO) and dihydroxyacetone (DHA), both of which are Unique Manuka Factor (UMF), contained uniquely and naturally in Manuka nectar. This was done to disguise the low-grade Manuka honey as high-grade and increase the commercial advantage. DHA is contained organically in Manuka flowers, which converts in the honey to MGO, constituting its highly valued anti-bacterial properties. However, synthetic DHA has always been used in tanning lotion but never in food. Thus, it has never undergone the necessary food safety tests. Plus, the analytical test to differentiate between synthetic and naturally occurring DHA and MGO is expensive, hence not routinely carried out by authority (Taylor, 2019). This case demonstrates the extent to which a fraudster would go for economic gain. Food fraud is indeed riskier than traditional food safety negligence since the adulterants are unconventional, which are designed to avoid detection.

\subsection{Types of honey fraud}

Increasing demand and commercial value of honey motivate falsification and adulteration in honey (Anklam, 1998). Generally, problems in honey fraud relate to aspects of safety and quality. Scanning through the fraudulent cases that occurred in the past, adulteration practices mostly involve fraudulent extensions with sugar syrups and mislabeling or misrepresentation relating to the floral or geographical origin.

Ever since the availability of cheap sugar syrup, producers often dilute honey with other less expensive sweeteners to increase financial profit. Although sugar addition does not pose a significant health threat, consumers taking honey for its nutritional benefits, particularly as a replacer for sugar, could compromise their health by not being informed. Random sampling by authority often finds traces of sugar cane, corn syrup, rice syrup, and beet sugar syrup in adulterated honey. At times, honey fragrance and bits of beeswax are also added to make it look like pure honey (Chiasson, 2019; CTV Montreal, 2017; Sattha, 2017; Test Sante, 2017). Some producers even artificially added enzymes such as amylases to mask honey adulteration with syrups to pass enzymatic activity testing. To protect consumers' interests and ensure fair commercial practices, the Codex Stand 12-1981 Standard for Honey and Honey Directive 2001/110/EC set out a clear definition and composition criteria for honey. Only products which consist of $100 \%$ honey can be sold under the label "honey." Legally, a honey blend can be marketed with the condition that it is not labeled as "honey" and has no intention to deceive. Honey Directive 2001/110/EC even included Bakers' honey to accommodate industry needs of industrial honey for the production of food products such as cereals. Ultimately, consumers should have the right to be informed and the right to choose.

Another common fraudulent practice in honey is the misrepresentation of its country of origin or botanical source. According to its floral source, honey can be classified as either monofloral (or unifloral) or multifloral (or polyfloral). Monofloral honey is perceived as higher quality than multifloral honey, hence 
more susceptible to adulteration. To deserve the title as monofloral, pollen from a specific plant must primarily constitute its main characteristics (Test Sante, 2017).

Honey can also be classified according to its geographical origin. Within the EU, honey being processed and prepared in given geographical areas bear the labels of protected designated origin (PDO) and protected geographical indication (PGI). PDO and PGI honey generally presents exclusive, refined flavor and taste and are perceived as high-quality products. Consequently, they are highly susceptible to adulteration (Suarekkam, 2017). In general, honey being the specialties of a specific region, are more prone to incorrect labeling or fraudulent admixing with lower-cost and low-quality honey (Raicaldo, 2016; The Debate, 2018). Apart from labeling retail products, wholesale honey in drums is even more critical to meet labeling specifications (TN, 2019).

Authority commonly uses melissopalynological analysis to determine the honey's exact geographical origin and botanical source (Test Sante, 2017). Pollen is the only foolproof fingerprint to honey's origin. However, it is argued that some non-compliance related to botanical sources in labeling was probably unintentional since bees forage a wide variety of plants (European Commission [EU], n.d.). Apart from that, globally harmonized and standardized standards are still absent as honey is a natural product with large compositional variations depending on its geographical origin, botanical source, and environmental factors. Currently, the lack of compositional data (chemical fingerprints) of authentic honey remains a caveat (European Commission [EU], 2018).

\subsection{Challenges in tackling honey fraud}

Since food fraud is an intentional act designed not to be detected, Dr. Van Ruth proposed to look at food fraud vulnerabilities from a criminology standpoint using Routine Activity Theory from Cohen and Felson. Like other organized crimes, the vulnerability of honey fraud heightens with the presence of these three elements: (1) a motivated offender, (2) a suitable target, and (3) the absence of control measures which in our case is the low traceability system.

In conclusion, the financial motivation of producing and selling adulterated honey is a fundamental issue in the existence of honey fraud. Fake honey proliferated due to retailers' extreme focus on high margins with low buying cost - for example, the case between Uruguayan honey and Brazilian honey (Portal 180, 2016). Brazilian honey has a higher commercial value due to organic certification, backed by a strong honey lobby in Brazil. Using the reasoning of having Amazon and a vast natural area, all honey from Brazil is certified organic. Unfortunately, this is not the case for Uruguay honey. Although Uruguay is situated directly beside Brazil, only less than $10 \%$ of Uruguay honey is certified organic. Hence, Uruguay producers prefer to smuggle and sell their honey to Brazilian importers due to the financial incentives of getting a better profit margin for both the producers and importers. This undercutting in price creates an extraordinarily competitive and unsustainable market.

Often, small local honey beekeepers find it hard to make ends meet, leading to fraudulent practices of adding sugar syrup in honey, mixing low-quality honey with higher quality, or misrepresenting honey as a higher commercial value honey (Chiasson, 2019). Moreover, the decline in bees' health and beekeeping activities negatively impacts the supply of honey. This creates more attempts for fraudulent practices to catch up with the increase in demand. Aside from the extreme climate changes, loss of natural areas, and indiscriminate use of insecticides, colony collapse disorder is another new phenomenon still poorly understood that is adversely affecting the apiculture sector.

Demonstrating businesses' sheer greed for profit, ultra-filtered or "UF" honey is now the real threat to honey's authenticity internationally. UF honey is not regarded as honey by most honey experts since all impurities and pollen traces could be removed through the ultra-fine ceramic or carbon filter (Durham, 2004). The FDA bans the importation of UF honey. Ultra-filtration can remove or mask floral fingerprints and indicators of added sweeteners or contaminants. Microscopic analysis of the pollen spectrum is still, to date, 
the reference method for the determination of the botanical and geographical origin of honey (Elflein, 2015). Ultra-filtering uses a high-tech procedure requiring state-of-the-art processing facilities.

On the other hand, traditional filtering is a standard industry practice to create shelf-stable honey. It eliminates chunky extraneous particles like traces of wax, debris from the hives, sugar crystals, and other visible contaminants while leaving most of the pollen in place. Ultra-filtration can be considered as an unnecessary deceptive practice since it does nothing but cost money. It also diminishes the honey's quality by destroying the taste, aroma, color, and nutritional compositions in honey. Hence, in many cases, the only logic is to assume UF honey on the market shelves is none other than adulterated honey.

A motivated fraudster will perpetually devise new tactics to circumvent the system. Nonetheless, strengthening the traceability system is still of paramount control measure in protecting honey authenticity. Detection methods for authenticating honey are not an issue as researchers are continuously developing better and more advanced detection methods, especially those that are portable and easier to handle for faster onthe-spot testing, such as using infrared spectroscopy (Guelpa, Marini, Plessis, Slabbert \& Manley, 2017; Agroinformacion, 2018). However, as the supply chain becomes more convoluted, traceability becomes harder, which increases the risk of adulteration. Origin masking through transshipment is one of the biggest problems faced by regulators in authenticating honey. Honey goes through a complex web with low traceability involving multiple transactions from producers to wholesalers to distributors to retailers before reaching consumers. Consequently, a low traceability system for honey authenticity will affect consumers' trust in honey quality assurance.

\section{Conclusion}

The importance of combating honey adulteration lies in the impact it harbors. Firstly, in protecting consumers and secondly, in preserving the apiculture sector. Fundamental consumer rights relevant to purchasing fraudulent honey are the right to safety, the right to be informed, and the right to choose. Deceptive advertising is considered a fraud. At the same time, the addition of unconventional and uncontrolled adulterants creates an undesirable health risk to consumers who are at the end of the supply chain (Oroian et al., 2018). On the other hand, fighting honey adulteration ultimately goes back to the importance of preserving the apiculture sector. Adulteration of honey undermines fair competition between bee producers and impairs marketplace integrity. In the long run, with the decline in beekeeping activities, sustainability in the environment and agriculture will be adversely affected since pollination by bees is vital to the nation's food security and ecological balance. It is crucial to strengthen and enhance the current traceability system since greedy and manipulative producers might unscrupulously take advantage of loopholes in the system to their benefit, leading to legitimate businesses and consumers' detriment.

\section{Acknowledgements}

The authors would like to thank everyone who has contributed directly or indirectly to this paper's writing.

\section{References}

Agro Informacion. (2018, December 17). They develop a method that detects the adulteration of honey quickly and with $100 \%$ reliability.

Anklam, E. (1998). A review of the analytical methods to determine the geographical and botanical origin of honey. Food chemistry, 63(4), 549-562.

Aries, E., Burton, J., Carrasco, L., De Rudder, O., \& Maquet, A. (2016). Scientific support to the implementation of a coordinated control plan with a view to establishing the prevalence of fraudulent practices in the marketing of honey. European Commission, Belgium, 38.

Bennett, C. (2013, Sep 30). One honey heist to rule them all [Blog post]. https://www.farmprogress.com/blog/onehoney-heist-rule-them-all 
Bottemiller, H. (2013). "Honeygate" Sting Leads to Charges for Illegal Chinese Honey Importation. Food Safety News Breen, T. (2010, September 24). States expand efforts to combat 'funny honey'. The San Diego Union-Tribune.

Chiasson, A. (2019, July 25). Fake honey still pouring into Canada, and local beekeepers are feeling the sting. CBC News. https://www.cbc.ca/news/canada/toronto/food-fraud-fake-honey-cfia-crackdown- 1.5222486 ? cmp=rss

Codex Stan 12-1981 Standard for Honey. (2019). http://www.fao.org/fao-who-codexalimentarius/thematicareas/nutrition-labelling/en/\#c452837

Coursey, M. J. \& Caryl, B. B. (2013). Massive honey smuggling sting signals continued crack-down on international trade fraud. Thomson Reuters World Trade Executive 2013. 3.

Durham, M. (2004). bitter taste of honey. American bee journal.

EcoDiario.es. (2018, January 3). The European Parliament demands funds to protect bees and combat the adulteration of honey.

Molan, P. C. (1996). Authenticity of honey. In Food authentication (pp. 259-303). Springer, Boston, MA.

Europa NU. (2018, March 1). Bees and beekeepers: MEPs want an EU-wide survival strategy.

F. Ulberth: Advances in Testing for Adulteration in Honey, Advances in Food Authenticity Testing, A volume in Woodhead Publishing Series in Food Science, Technology and Nutrition (2016) Pages 729-753.

Council Directive 2001/110/ European Commission of 20 December 2001 relating to honey.

Stöbener, A., Naefken, U., Kleber, J., \& Liese, A. (2019). Determination of trace amounts with ATR FTIR spectroscopy and chemometrics: 5-(hydroxymethyl) furfural in honey. Talanta, 204, 1-5.

European Parliament. (2018, February 8). Motion for a European Parliament Resolution on prospects and challenges for the EU apiculture sector.

Food Adulteration Incidents Registry. (n.d.). https://incidents.foodprotection.io/search

Manning, L. (2016). Food fraud: Policy and food chain. Current Opinion in Food Science, 10, 16-21.

Food Fraud Summary Month Reports. (n.d.). https://ec.europa.eu/knowledge4policy/publication/food-fraud-summarymonth-reports_en

Jeffrey C. Moore, John Spink, Markus Lipp. Development and Application of a Database of Food Ingredient Fraud and Economically Motivated Adulteration from 1980 to 2010. Journal of Food Science, 2012

Guelpa, A., Marini, F., du Plessis, A., Slabbert, R., \& Manley, M. (2017). Verification of authenticity and fraud detection in South African honey using NIR spectroscopy. Food Control, 73, 1388-1396.

Moore, J. C., Spink, J., \& Lipp, M. (2012). Development and application of a database of food ingredient fraud and economically motivated adulteration from 1980 to 2010. Journal of food science, 77(4), R118-R126.

van Tonder, E., Enemy, K. Y., Plant, C., Rooms, C., be Contaminant-Free, C. A. M., \& Product, F. recent history.

Oroian, M., Paduret, S., \& Ropciuc, S. (2018). Honey adulteration detection: voltammetric e-tongue versus official methods for physicochemical parameter determination. Journal of the Science of Food and Agriculture, 98(11), 43044311.

Franciane Marquele-Oliveira, Daniel Blascke Carrão, Rebeca Oliveira de Souza, Nathalia Ursoli Baptista, Andresa Piacezzi Nascimento, Elina Cássia Torres, Gabriela de Padua Moreno, Andrei Felipe Moreira Buszinski, Felipe Galeti Miguel, Gustavo Luis Cuba, Thaila Fernanda dos Reis, Joelma Lambertucci, Carlos Redher and Andresa A. Berretta (March 15th, 2017). Fundamentals of Brazilian Honey Analysis: An Overview, Honey Analysis, Vagner de Alencar Arnaut de Toledo, IntechOpen

Svetlicinii, A. (2018). fake food" as a new ingredient in the "cuisine juridique": A case for "regulatory co-opetition. Medicine and Law, 37(1), 175-191.

Sattha, C. (2017, May 24). Adulterated honey seized in Chiang Mai. Bangkok Post. https://www.bangkokpost.com/thailand/general/1255515/adulterated-honey-seized-in-chiang-mai

Schneider, A. (2011, December 9). Mislabeled Chinese honey leads to criminal busts. Food Safety News.

Suarekkam E. (2017, November 21). 600 kilos of honey from the continent seized from a beekeeper in PDO. Corse Matin.

Taylor, R. (2019, January 30). New Zealand brings first 'fake manuka honey' prosecution. https:/www.theguardian.com/world/2019/jan/31/new-zealand-brings-first-manuka-honey-prosecution-chemicals Test Sante. (2017, January 20). The unique origin of often dubious honeys.

The Debate. (2018, April 3). Honey from Mexico or China.

TN. (2019, March 7). You can only market traceability honey from its origin. https://tn.com.ar/economia/solo-se-podracomercializar-miel-con-trazabilidad-desde-su-origen_975497 
U.S. Attorney's Office, Northern District of Illinois. (2013, February 20). Two companies and five individuals charged with roles in illegal honey imports; avoided \$180 million in anti-dumping duties. Department of Justice.

van Ruth, S. M., Huisman, W., \& Luning, P. A. (2017). Food fraud vulnerability and its key factors. Trends in Food Science \& Technology, 67, 70-75. 